\title{
Saltwater Intrusion in Jizan Coastal Zone, Southwest Saudi Arabia, Inferred from Geoelectric Resistivity Survey
}

\author{
Saad Mogren \\ Department of Geology and Geophysics, College of Science, King Saud University, Riyadh, Kingdom of Saudi \\ Arabia \\ Email: smogren@ksu.edu.sa
}

Received 27 February 2015; accepted 22 March 2015; published 26 March 2015

Copyright @ 2015 by author and Scientific Research Publishing Inc.

This work is licensed under the Creative Commons Attribution International License (CC BY). http://creativecommons.org/licenses/by/4.0/

c) (i) Open Access

\section{Abstract}

This work focuses on the causes of water quality deterioration in the coastal plain of Jizan area, southwest Saudi Arabia using vertical electrical sounding (VES) surveys. Schlumberger electrode array is used in the study with the current electrode spacing ranging from 400 to $600 \mathrm{~m}$ to delineate the thickness of the shallow aquifer and its possible interaction with the sea water. The differences in resistivity are associated with the variations in lithology and groundwater saturation and salinity. The interpretation of VES curves reveals low resistivity zones characterizing the study area. These zones reflect saline water intrusion in the coastal aquifer. Generally, it is observed that the resistivity of saturated zone decreases towards the sea, indicating the influence of seawater. Based on the interpretation of the constructed resistivity pseudo-sections and 1-D sequential inversion models, three factors are identified to control the seawater intrusion into the shallow groundwater aquifers: 1 ) presence of faults that contribute extensively in the seawater intrusion as the seawater invades the coastal aquifers through the crushed rocks in fault zones related to the Red Sea rifting, 2) over-withdrawal of groundwater from the coastal aquifers, resulting in saline water intrusion from the sea into the freshwater aquifer, and 3) the lithological variation where the alluvial sediments of the ancient buried wadi (dry valley) channels provide potential pathways for saltwater intrusion and make a hydraulic connection between the aquifer and the sea water.

\section{Keywords}

Geoelectric Resistivity, Seawater Intrusion, Jizan Area, Saudi Arabia 


\section{Introduction}

Clean water is demanded for daily life and a basic requirement for economic development. Saudi Arabia is an arid country with very little rainfall and no permanent rivers or lakes. With the fast growth and development, the demand for fresh water has increased very rapidly. Due to the absence of surface water resources, groundwater forms the major source of water in Saudi Arabia. Since 1950s, the government undertook major efforts to locate, map and estimate the available groundwater reserves so as to use them as a potential source for future water supply. As a result, tens of thousands of water wells have been drilled in the most promising areas for agricultural, domestic and industrial usage.

The present study area has an increasing demand for additional and sustainable water resources due to the daily need of water for economic development and demographic growth in Jizan. Groundwater exploration and management thus becomes the need of the hour in such areas for sustainable development. Geophysical methods for the subsurface investigation can contribute to the coastal surface and ground water characterization, see for example [1]-[5]: Balia et al. [6] studied water salinization at the Muravera plain in southern Sardinia, Italy by applying a combination of geophysical techniques. Batayneh [7] made a new study for detecting subsurface fresh and saline water in the eastern Dead Sea coastal aquifers in Jordan utilizing electrical resistivity methods while Koukadaki et al. [8] used integrated geophysical observations and analysis to characterize the hydrogeology of a coastal aquifer. Geoelectric methods were applied to monitor seawater intrusion in different parts of the world (as in [9]-[12]). Cimino et al. [13] carried out vertical electrical sounding in the coastal plain of Acquedolci (Northern Sicily-Italy) to assess seawater intrusion, while Khalil [14] studied the salt water intrusion from the Gulf of Suez by applying a direct current resistivity geoelectric method.

In recent years, many coastal areas in Saudi Arabia witnessed decline in groundwater levels and seawater intrusion due to overdraft of groundwater to cope with the increasing water demand. In the Jizan area, especially the coastal plain, the local people complain about the increasing salinity of the existing water wells. It is expected that the groundwater quality deterioration in the study area is due to ongoing excessive water pumping and decrease in precipitation. In this study, VES surveys were carried out using surface Schlumberger electrode array to provide accurate interpretation on the possible interaction between the coastal shallow aquifers and sea water.

\section{General Geology}

Rock units ranging in age from Proterozoic to Cenozoic are considered as the cover rocks in the Jizan area (Figure 1). The Proterozoic rocks present in the eastern part of the study area are mainly metasediments and metavolcanics that are generally represented by the Sabya Formation, Baish and the Abha groups [15]. The Paleozoic and Mesozoic rocks are primarily sandstone and mostly represented by Wajid Formation in the study area. The Cenozoic rocks are represented by the Tertiary and Quaternary basalts and alluvial deposits (Figure 1). Tertiary rocks cover many parts of the study area forming a thick sequence of clastic sedimentary rocks that deposited in fault bounded troughs and covered in some places by basaltic flow. Pleistocene to Holocene deposits widely cover the coastal plain, including Quaternary sand, alluvial deposits, gravel, some recent evaporates and raised marine terraces and reef limestone.

According to Hussain and Ibrahim [16] Wadisgenerally follow the main fracture system. The drainage system in the study area is generally of rectilinear nature, sub-parallel to the Red Sea. Typically a main wadi channel is represented by a width that varies from about 100 to $1000 \mathrm{~m}$ and the average thickness of the water bearing unit ranges from about $3 \mathrm{~m}$ in the upstream part to about $30 \mathrm{~m}$ or more in the downstream. Aquifers in the study area contain alluvial deposits of heterogeneous assemblage of unconsolidated cobbles, gravels, sand and silt. In the upstream area the coarse units predominate while grain size decreases in the downstream direction towards the coastal plain. Water levels range from about $110 \mathrm{~m}$ above sea level in the head waters to about $5 \mathrm{~m}$ in the coastal plain. However, most of the surface runoff of these wadis does not reach the Red Sea.

\section{Hydrogeology}

Groundwater is the main source of water supply in Saudi Arabia. Previous studies, e.g. [16] [20]-[22] had identified two types of groundwater in Saudi Arabia shallow alluvial aquifers underneath the wadi systems, and deep rock aquifers, usually comprising by sandstone and limestone. The deep rock aquifers are usually confined, 


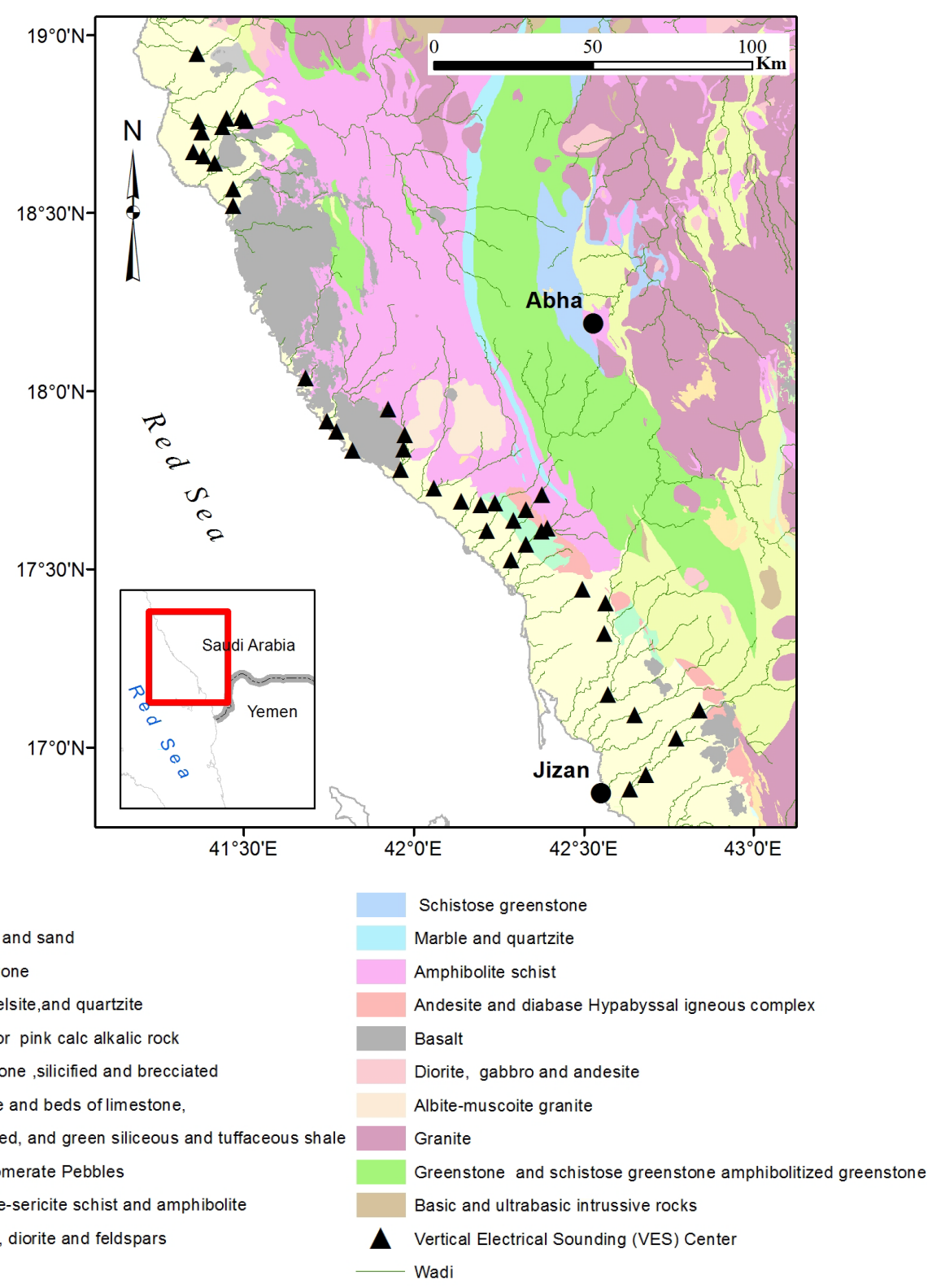

Geology

Gravel and sand

Sandstone

Slate, felsite, and quartzite

gray or pink calc alkalic rock

Limestone, silicified and brecciated

Laterite and beds of limestone,

Gray,red, and green siliceous and tuffaceous shale

Conglomerate Pebbles

Chlorite-sericite schist and amphibolite

Quartz, diorite and feldspars

Figure 1. Geologic map of the study area (modified from [15] [17]-[19]).

covering larger areal extent and hold some amount of fossil groundwater. The alluvial shallow aquifer is the primary source of water for domestic, agriculture and industrial water consumptions in the Jizan. Recharge to these aquifers are derived either from the mountainous areas in the east and southeastern parts of the study area, or from local surface water infiltrations, as mentioned in [23] [24] groundwater in the study area is present within two geologic units; the alluvial deposits of the wadi systems and the clastic coarse members of the Cretaceous-Tertiary sedimentary succession [21]. The drainage systems in the coastal area are shown in Figure 2 which is prepared using the digital elevation model (DEM) data of 3 arc second resolution. It shows three distinctive drainage patterns in the directions of NE, NW and E-W.

Geomorphologically Jizan area has two distinct units; the arid coastal plain to the west known as the Tihama, and Precambrian mountain range to the east. The plain is approximately $400 \mathrm{~km}$ long spreading in a NW-SE direction with an average width of $30 \mathrm{~km}$. The plain is adjacent to the Red Sea in the west and bordered by the foothills of the mountain chain to the east (Figure 2). The average annual rainfall is low in the area, however, there are some heavy but few rainy days during the year. Water reservoir in Jizan area acts like a subterranean 


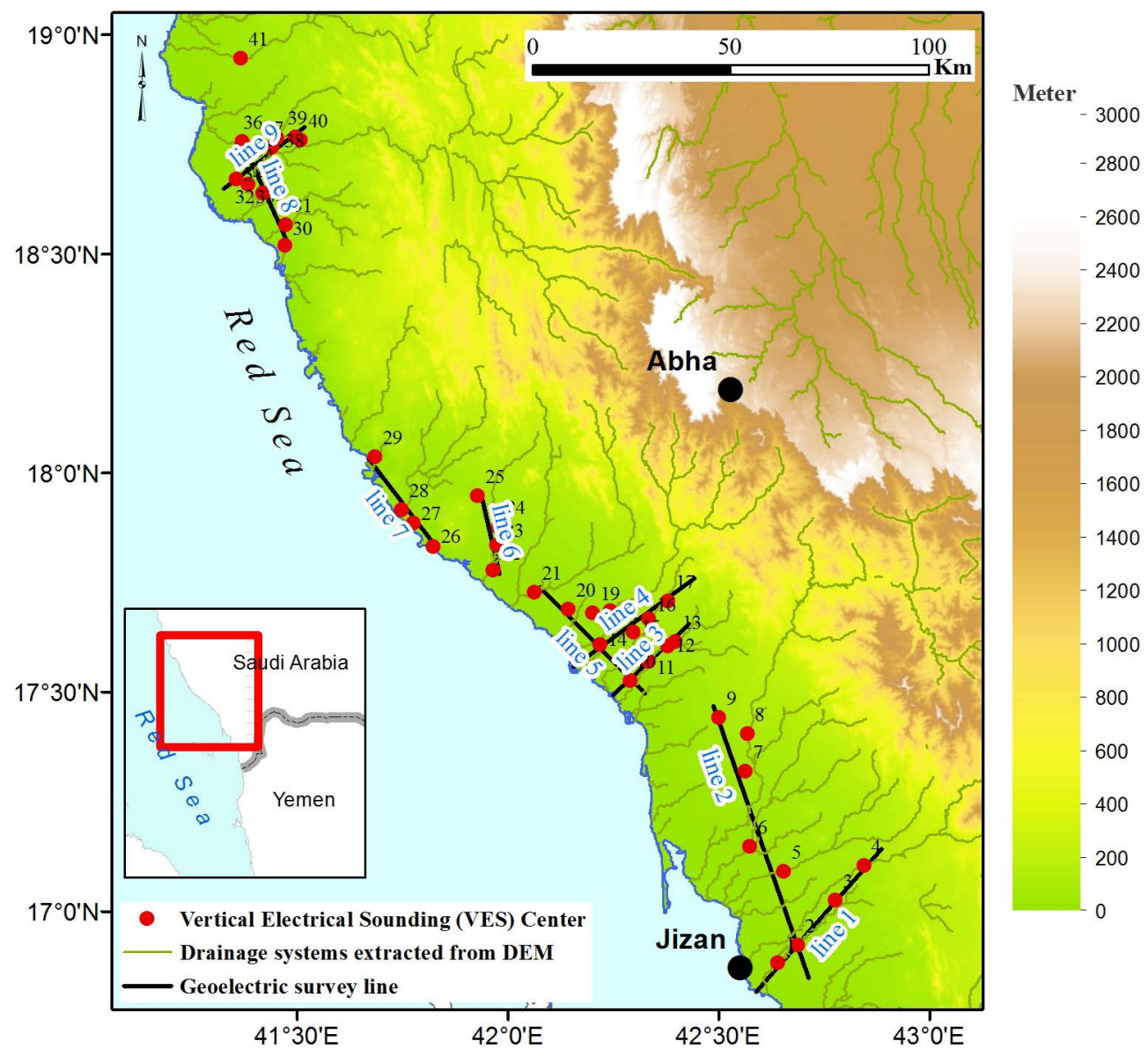

Figure 2. Digital elevation model of Jizan coastal area shown also the locations of VES stations acquired during the geoelectric resistivity survey.

channel system, similar to the drainage system. Therefore, groundwater flow is almost parallel to the wadi drainage. Maximum thickness of the water body is supposedly thicker than 100 meters at depths of $5 \mathrm{~m}$ to $35 \mathrm{~m}$ [22]. The hydraulic gradient varies from 0.013 in the up-stream to 0.004 in the down-stream. According to $\mathrm{Al} \mathrm{Hazmi}$ [24], the average transmissivity is $173 \mathrm{~m}^{2} /$ day; the average hydraulic conductivity is $2.163 \mathrm{~m} /$ day and the average storability is 0.16 .

\section{Data Acquisition and Processing}

The surface electrical resistivity method is a useful tool in determining seawater intrusion in coastal areas for its capability to discriminate the large resistivity contrast between the presence of seawater that strongly reduces the resistivity values and saturated freshwater layers. VES survey reported in the present study was carried out with the primary objective of obtaining information on the hydrogeological behavior of the aquifers, the subsurface liuthology and groundwater salinity. Surface Schlumberger electrode array with electrode spacing varying between 1 to $600 \mathrm{~m}$ was used for VES survey. Location and distribution of the VES stations are shown on Figure 2 , a total of 41 VES was conducted using the resistivity meter SyscalR2.

For processing the VES field data in terms of the layer parameters, 1-D inversion technique using IX1D-Interpex software was used (Interpex). This software produces the resistivity model, fitting the acquired field data with the least root mean square (RMS) error between the synthetic data generated from the model and the actual data. This method of iteration was performed until the fitting errors between field data and synthetic model curve became least and constant. The output of true resistivity values for the subsurface layers, their respective thickness and depth values from the ground surface, obtained by interpreting field data and by curve-fitting to input data using IX1Dsoftware are shown on Figure 2. 
The electrical resistivity of sediments depends on lithology, water content, clay content and salinity [25] [26]. Some interpretation problems for VES can occur when mapping subsurface salinity, since resistivity for salt water, saturated clay and sand overlaps. It is, therefore, important to correlate the VES results with the lithological and hydrological information of nearby borehole data as shown in Figure 4.

The apparent resistivity data were next contoured as pseudo-sections in order to illustrate the vertical and horizontal distribution of the resistivity. The true resistivity and thicknesses of the interpreted geoelectric resistivity layers are plotted as 1-D sequential inversion model below the sounding locations Figure 5, Figure 6 and Figure 7 and listed in Table 1.

\section{Data Interpretation}

Owing to the differing character of features in the apparent resistivity curves, the VES stations show different types of curves. The interpretation results reveal significant variations in subsurface resistivity of the coastal rock units in the study area. The types of VES curves were defined in terms of the number of geoelectrical layers and their resistivity relationship. If the lateral variations in resistivity in the shallow subsurface units as a result of heterogeneity of lithology and soil moisture content are ignored, most of the VES resistivity curves show a dominant trend of decreasing resistivity (for example, VES 1, 2, 3, 5, 6, 7, 10, 21, 22, 24, 26, 28, 34, 35, 36, 37 and 41). A representative example of this type of sounding curves with their 1-D inversion models and data fit are shown in Figure 3(a).

The second type of the resistivity curves shows flat and low resistivity with values of about $5 \mathrm{ohm} \cdot \mathrm{m}$ (Figure 3(b)). The third type of the field curves reflect the presence of geoelectric resistivity layers with resistivity decreasing with depth until the highly resistive bedrocks are reached at the bottom of the section $(\rho 1>\rho 2>\rho 3<$ $\rho 4$ ), for example, VES 4, 8, 11, 13, 14, 15, 16, 17, 18, 19, 20, 23, 31, 32, 33, 38, 40 (Figure 3(c)).

The outputs of the VES interpretation were verified using borehole data at two sites (Figure 4). The lithological information from the wells are available up to a depth of 30 meters The correlation between VES data and borehole data was found to be in close agreement with each other. The results from the analysis of VES data show that the well log data corroborates perfectly with the lithology. The top soil with dry sand is the first layer, coarse sand containing brackish groundwater is the second layer and alternate layers of sand and clay containing seawater is the third and fourth layers with resistivities of 49, 13.6, 9.8 and $3.9 \mathrm{ohm} \cdot \mathrm{m}$ respectively.

The apparent resistivity data that were acquired along nine survey lines (Figure 2) extending in the NE and NW directions were contoured as pseudo-sections (Figure 5, Figure 6 and Figure 7); four lines extend perpendicular to the Red Sea, while the other five are nearly parallel to the Red Sea coast. These pseudo-sections are together illustrated by a corresponding representation of the sequential inversion models. Data fit shows the change in true resistivity and thickness of geoelectric resistivity layers with depth. The saltwater interface can be seen on these pseudo-sections.

The present electrical resistivity survey was conducted and planned in the study area of Jizan based on the previously published results of the gravity and magnetic studies by Elawadi et al. [27] that delineated the subsurface structures that could affect the flow and accumulation of the groundwater in the study area. The apparent resistivity and the interpreted parameters of the subsurface layers are presented in the form of pseudo-sections, contour maps and sequential 1-D inversion model with data fit curves using Ix1D-Interpex (inversion software). The zones with saline groundwater either in the shallow or deep aquifer were separated based on their respective resistivity values.

The low resistivity zones present at variable depths across the geoelectric survey lines indicating groundwater contaminated with seawater. In some localities, it is observed that the upper surface of low resistive layers rise; indicating the rise of the saltwater surface. This could be a result of the unwise extraction from the shallow aquifer. The over draft of groundwater always results in the lowering of the water level and consequently the salinization process begins in the aquifer as the seawater flows forms the so called cone of ascension or up-coning of saline water surface. This is observed in VES 7 in (Figure 5(a)) where the true resistivity of the bottom layer decreases to $11 \mathrm{ohm} \cdot \mathrm{m}$ while, in VES 27 the resistivity of the bottom layer touches down to $2.0 \mathrm{ohm} \cdot \mathrm{m}$ (Figure 5(b)).

It is also noticed that the low resistivity layer reaches shallow depths in other localities, especially where the fault structures or wadi channels are present. In this case, it is therefore expected that the seawater flows through the crushed rock in fault zones or unconsolidated wadi alluvial deposits where the resistivity reaches $2.6 \mathrm{ohm} \cdot \mathrm{m}$ 

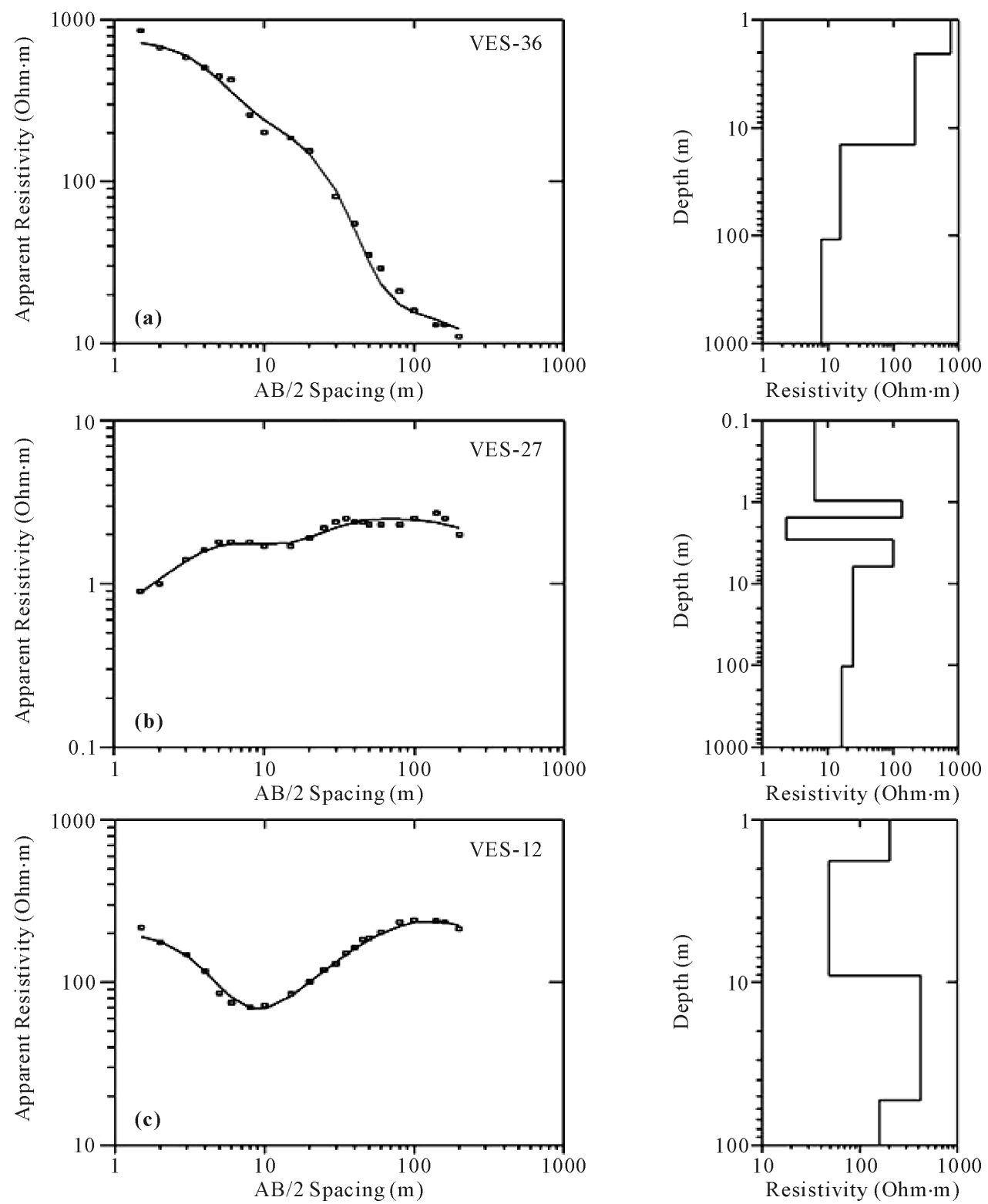

Figure 3. Typical example of the 1-D inversion model and data fit of representative examples of VES curves. (a) Shows decreasing resistivity with depth, (b) Show nearly flat low resistivities and (c) Show decreasing resistivity with depth till the high resistive appeared at the substream.
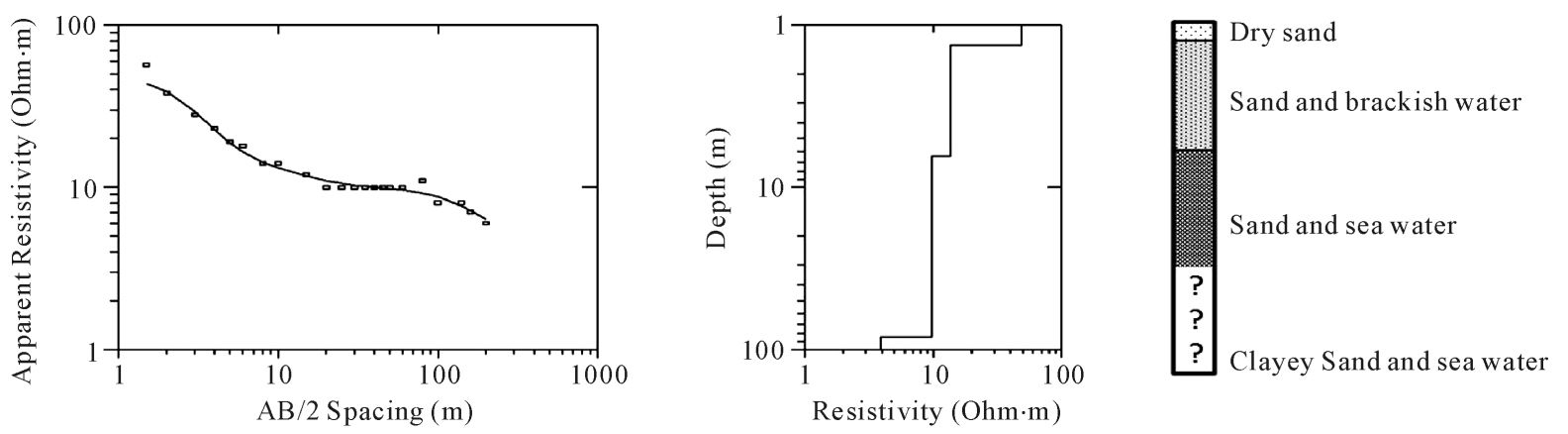

Figure 4. 1-D inversion model and data fit correlated with borehole data. 


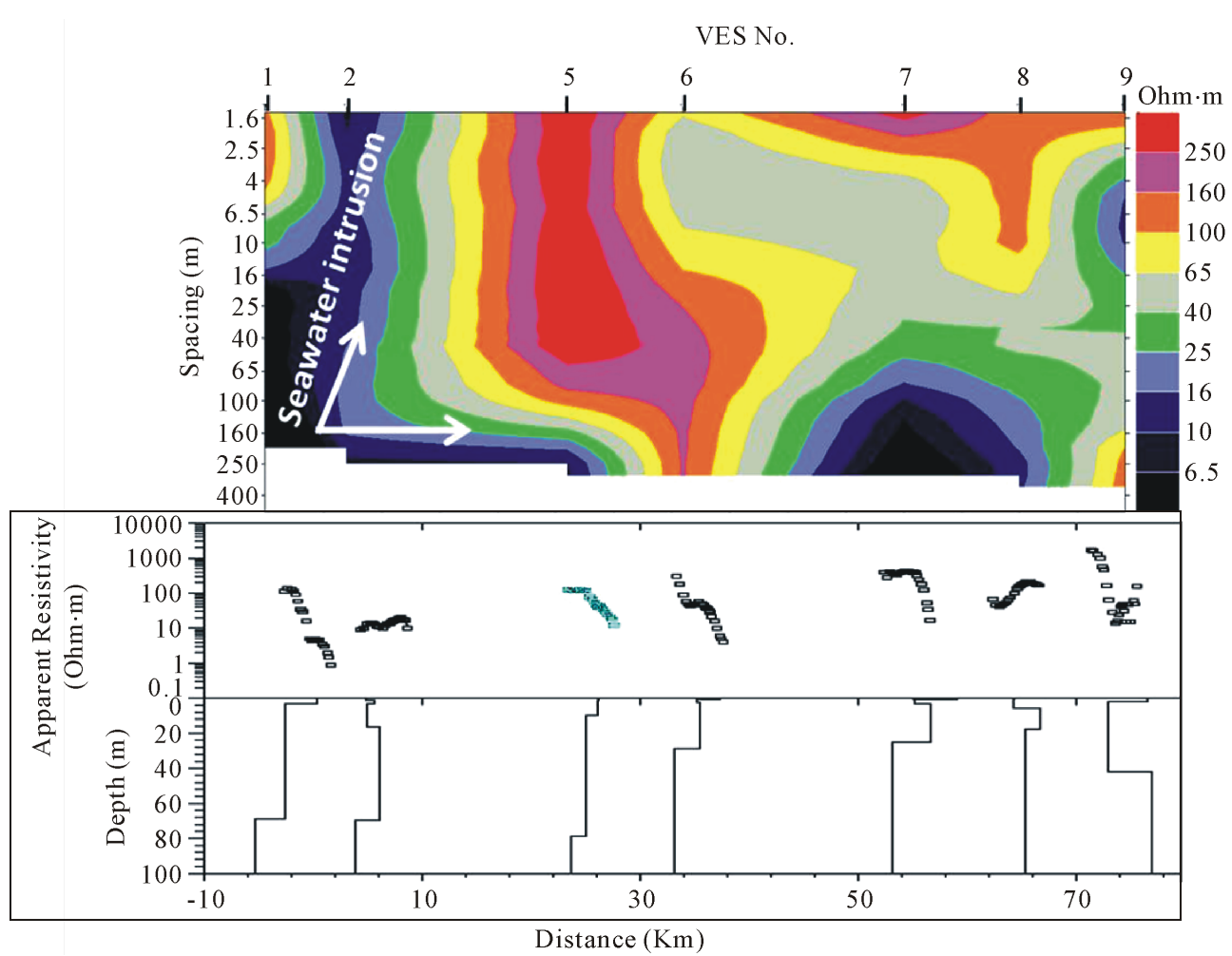

(a)

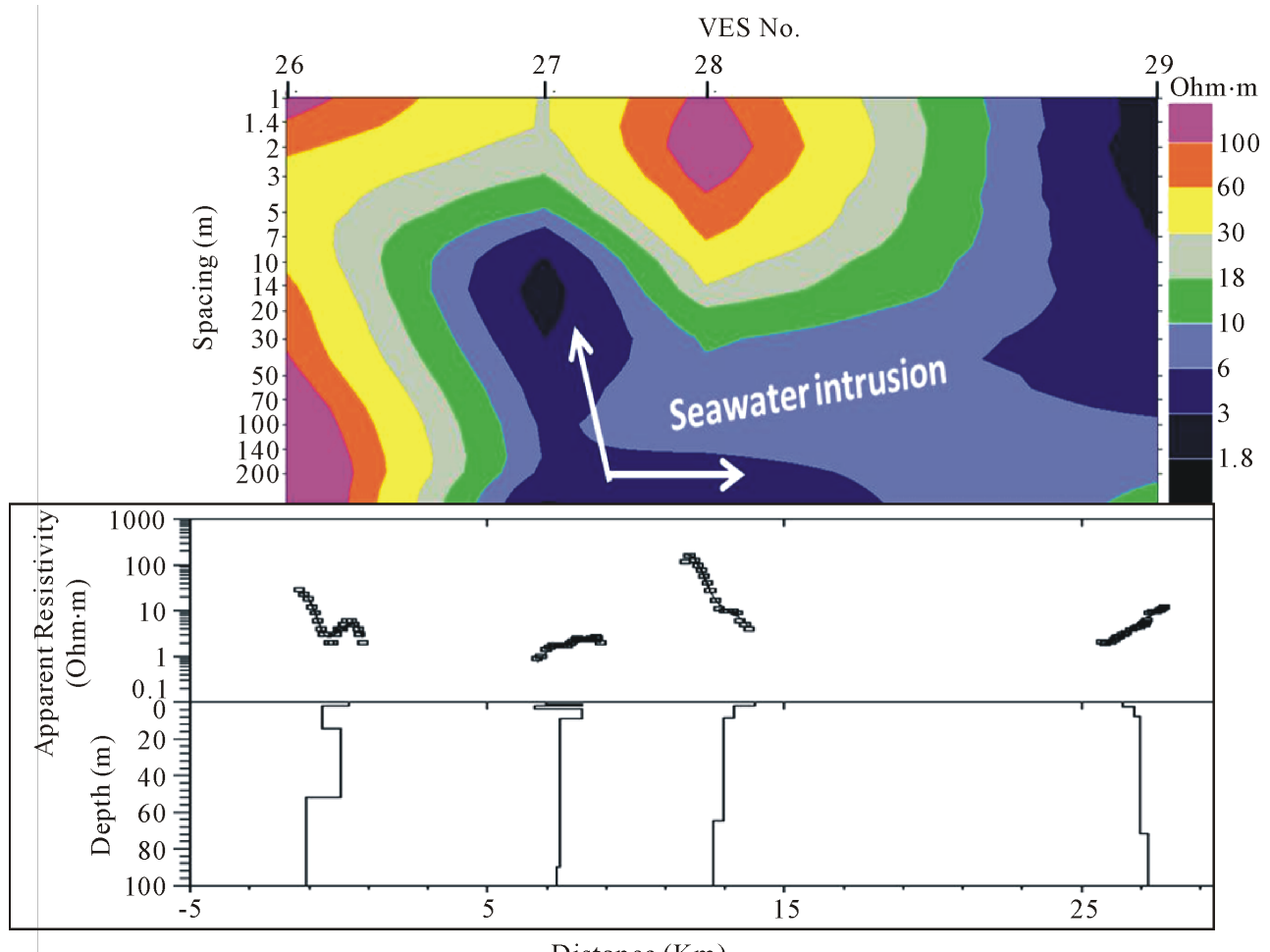

(b)

Figure 5. Examples of the pseudo-sections (top map) and 1-D sequential inversion models (bottom) and data fitting curves (middle) along geoelctric survey line-2 (a) and Line-7 (b). Note the up-coning of the low resistivity zones with blue color under VES 7 and VES 27 indicating seawater intrusions. 

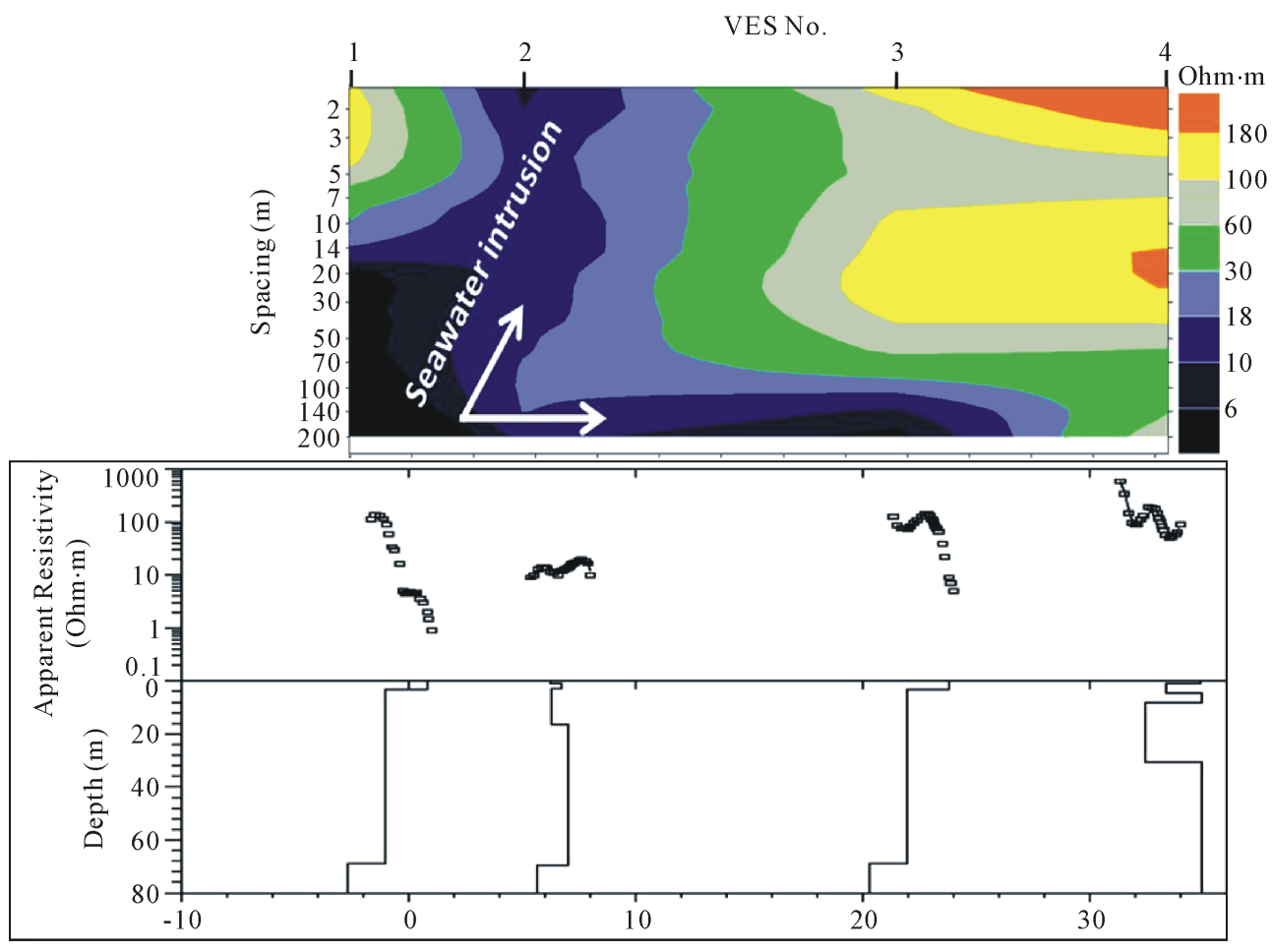

Distance $(\mathrm{Km})$

(a)

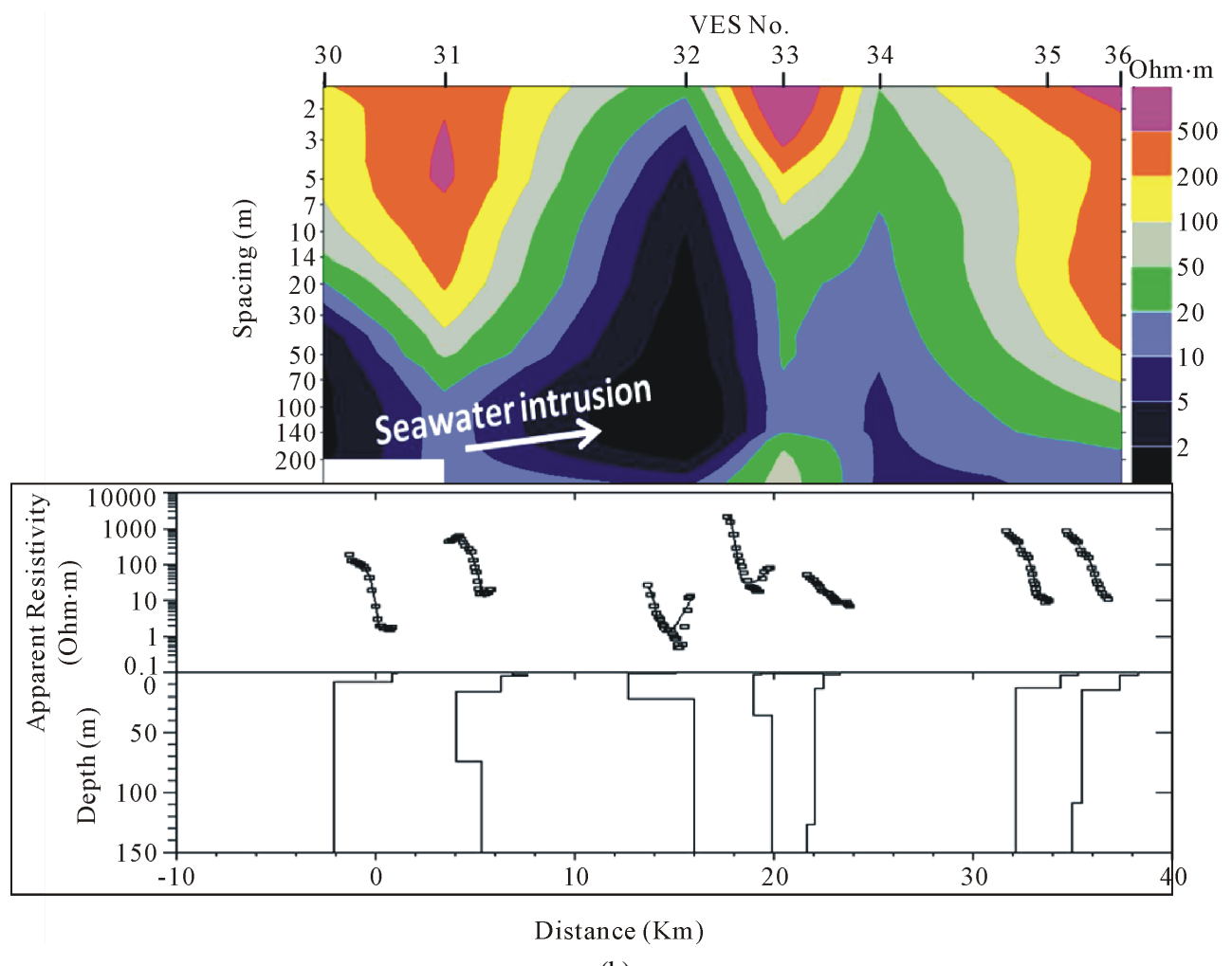

(b)

Figure 6. Examples of the pseudo-sections (top) and 1-D sequential inversion models (bottom) and data fitting curves (middle) along geoelctric survey line-1 (a) and Line-8 (b). Note the low resistivity layers with blue color under VES 2 and VES 32 reach shallow depths. 


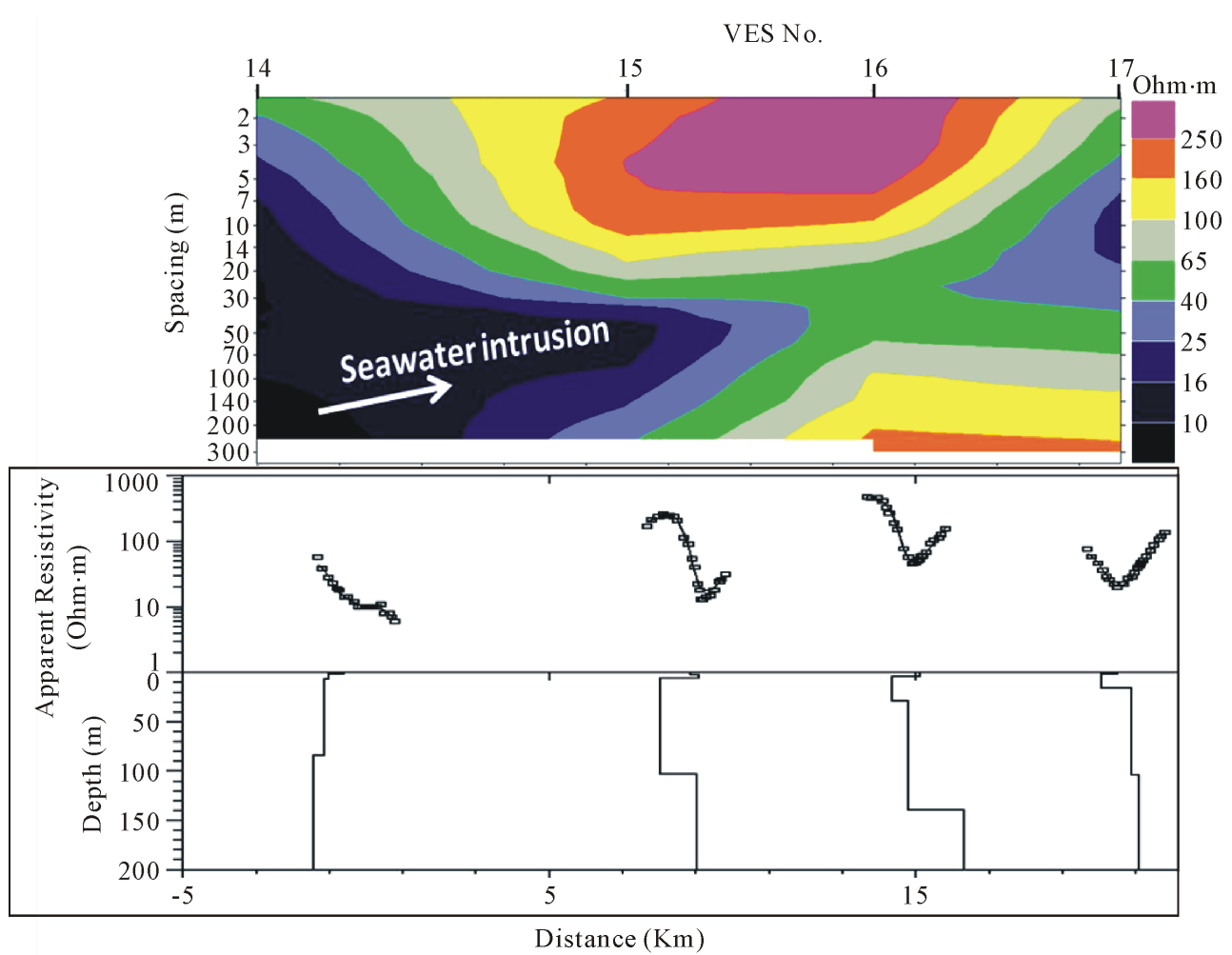

(a)

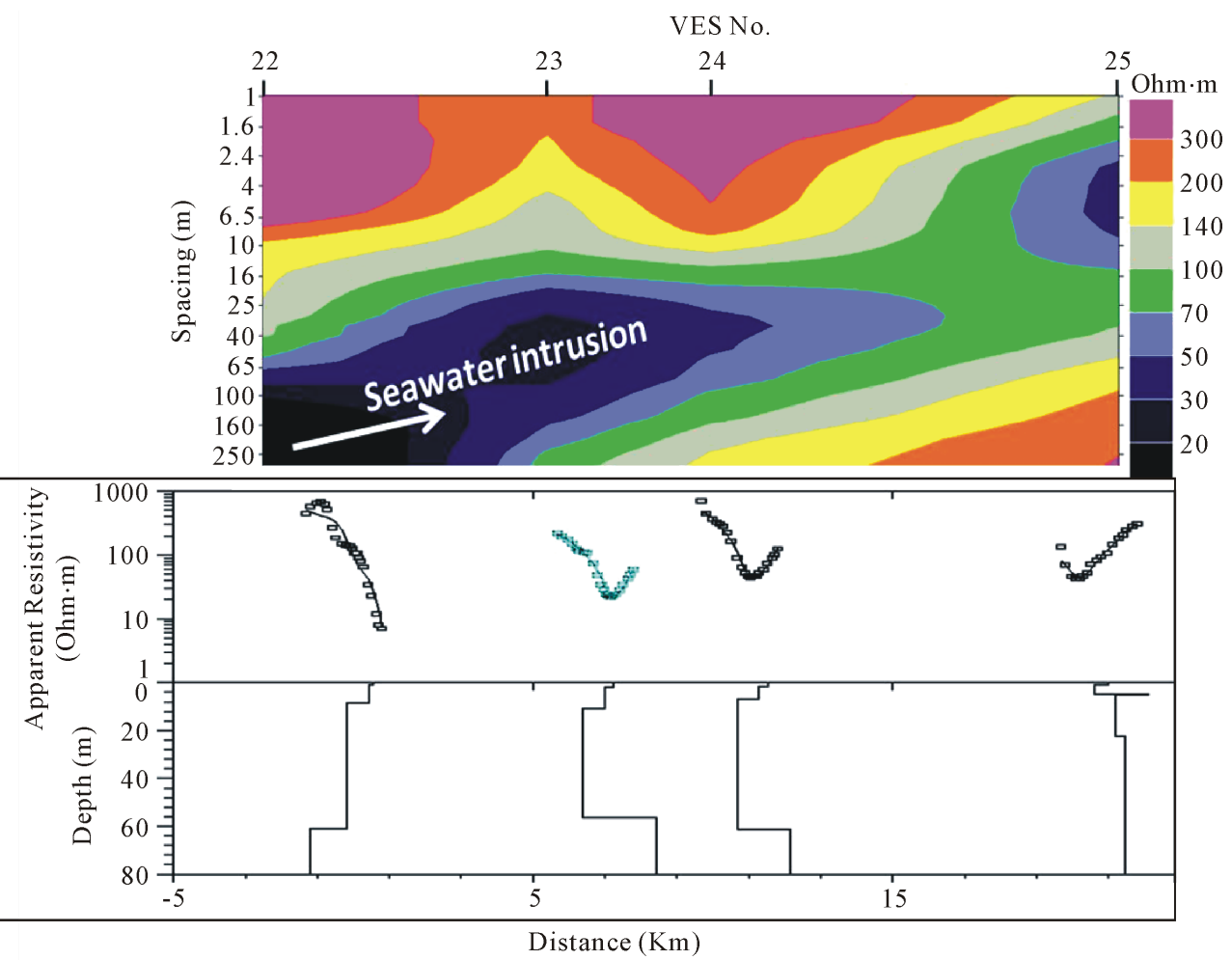

(b)

Figure 7. Examples of the pseudo-sections (top) and 1-D sequential inversion models (bottom) and data fitting curves (middle) along geoelctric survey line-4 (a) and Line-6 (b). Note the pinch out low resistivity layers with blue color that extends out laterally. 
Table 1. List of the true resistivities and thicknesses of the interpreted geoelectric resistivity layers.

\begin{tabular}{|c|c|c|c|c|c|c|c|c|c|}
\hline \multirow{2}{*}{ VES No. } & \multicolumn{2}{|c|}{ 1st Layer } & \multicolumn{2}{|c|}{ 2nd Layer } & \multicolumn{2}{|c|}{ 3rd Layer } & \multicolumn{2}{|c|}{ 4th Layer } & \multirow{2}{*}{$\begin{array}{c}\text { 5th Laye } \\
\text { Rho5 }\end{array}$} \\
\hline & Rho1 & h1 & Rho2 & h2 & Rho3 & h3 & Rho4 & h4 & \\
\hline 1 & 140.1 & 3.3 & 4.8 & 65.5 & 0.2 & ----- & ----- & ----- & ----- \\
\hline 2 & 7.7 & 0.9 & 18.7 & 2.1 & 8.9 & 13.3 & 32.9 & 53.4 & 2.6 \\
\hline 3 & 92.9 & 0.8 & 73.2 & 5.2 & 454.1 & 7.7 & 4.6 & ----- & ---- \\
\hline 4 & 993.5 & 0.8 & 63.0 & 3.9 & 1119.9 & 3.3 & 11.3 & 22.8 & 1119.9 \\
\hline 5 & 127.5 & 1.0 & 116.7 & 8.6 & 30.9 & 69.1 & 6.4 & ----- & ----- \\
\hline 6 & 434.6 & 0.9 & 39.2 & 1.6 & 51.2 & 26.1 & 3.6 & ----- & ----- \\
\hline 7 & 111.1 & 0.7 & 1100 & 0.2 & 125.4 & 2.4 & 644.4 & 21.7 & 11.0 \\
\hline 8 & 49.7 & 0.2 & 44.9 & 5.5 & 699.8 & 11.9 & 143.4 & ---- & ---- \\
\hline 9 & 1957.7 & 2.08 & 30.2 & 40.0 & 2988.1 & ----- & ----- & ----- & ----- \\
\hline 10 & 47.2 & 1.8 & 11.6 & 4.6 & 8.8 & 12.6 & 13.4 & 64.0 & 8.0 \\
\hline 11 & 1876 & 2.1 & 54.6 & 4.2 & 6.8 & 7.2 & 78.8 & ----- & ----- \\
\hline 12 & 203.8 & 1.8 & 48.4 & 7.3 & 420.4 & 44.0 & 159.7 & ----- & ----- \\
\hline 13 & 314.3 & 1.5 & 115.5 & 17.7 & 324.3 & 34.1 & 66.4 & ---- & ---- \\
\hline 14 & 49.1 & 1.3 & 13.6 & 5.1 & 9.9 & 77.2 & 3.9 & ----- & ----- \\
\hline 15 & 199.9 & 1.8 & 409.4 & 3.7 & 16.2 & 97.1 & 343.7 & ----- & ----- \\
\hline 16 & 455.0 & 3.8 & 41.0 & 25.3 & 172.4 & 109.9 & 1706 & ----- & ----- \\
\hline 17 & 70.0 & 1.6 & 18.0 & 13.9 & 221.8 & 88.6 & 427.5 & ----- & ----- \\
\hline 18 & 456.0 & 3.9 & 14.1 & 34.4 & 4624.0 & ----- & ----- & ----- & ----- \\
\hline 19 & 677.0 & 0.8 & 103.0 & 18.5 & 9.3 & 142 & 2345.0 & ----- & ----- \\
\hline 20 & 25.5 & 0.9 & 323.0 & 4.9 & 22.6 & 17.0 & 3.2 & 147 & 916.0 \\
\hline 21 & 26.7 & 1.1 & 321.0 & 5.0 & 59.4 & 20.0 & 10.8 & 75.3 & 2.2 \\
\hline 22 & 543.3 & 0.9 & 399.0 & 7.0 & 59.3 & 52.4 & 2.5 & ----- & ----- \\
\hline 23 & 209.6 & 1.8 & 96.5 & 8.8 & 15.0 & 45.8 & 8422.3 & ----- & ----- \\
\hline 24 & 507.6 & 1.5 & 226.5 & 5.3 & 38.3 & 54.7 & 3462.4 & ----- & ----- \\
\hline 25 & 96.3 & 1.0 & 31.3 & 3.9 & 3100.0 & 0.9 & 178.00 & 17.4 & 398.0 \\
\hline 26 & 27.7 & 1.9 & 2.10 & 12.6 & 12.0 & 37.5 & 0.4 & & \\
\hline 27 & 0.6 & 1.0 & 17.5 & 0.7 & 0.2 & 1.7 & 17.0 & 5.6 & 2 \\
\hline 28 & 184.0 & 2.0 & 23.0 & 6.6 & 8.9 & 56.1 & 3.0 & ----- & ----- \\
\hline 29 & 1.8 & 2.5 & 5.2 & 5.4 & 8.8 & 64.0 & 20.0 & ----- & ----- \\
\hline 30 & 139.4 & 1.3 & 98.5 & 6.5 & 1.7 & ----- & ----- & ----- & ----- \\
\hline 31 & 418.7 & 1.4 & 1147.8 & 1.6 & 193.2 & 13.1 & 8.3 & 57.8 & 49.0 \\
\hline 32 & 35.3 & 1.0 & 1.3 & 21.1 & 124.5 & ----- & ----- & ----- & ----- \\
\hline 33 & 3722.3 & 1.0 & 53.2 & 0.9 & 31.0 & 33.8 & 109.0 & ----- & ----- \\
\hline 34 & 47.7 & 1.9 & 16.1 & 11.6 & 8.4 & 113.0 & 5.0 & ----- & ----- \\
\hline 35 & 749.5 & 2.0 & 215.7 & 10.9 & 10.2 & ----- & ----- & ----- & ----- \\
\hline 36 & 749.5 & 2.0 & 212.5 & 12.3 & 15.4 & 94.3 & 7.9 & ----- & ----- \\
\hline 37 & 102.0 & 1.5 & 4093 & 2.2 & 61.3 & 24.3 & 17.9 & ----- & ----- \\
\hline 38 & 1049 & 0.8 & 88.0 & 15.3 & 0.8 & 17.1 & 9.8 & 14.4 & 157.0 \\
\hline 39 & 39.0 & 0.8 & 16.0 & 5.7 & 43.5 & 3.9 & 4.5 & 232 & 76.0 \\
\hline 40 & 398.0 & 1.3 & 95.7 & 7.3 & 7.1 & 22,6 & 0.4 & 87.0 & 482 \\
\hline 41 & 219.0 & 1.0 & 10,886 & 0.6 & 271 & 22.3 & 17.3 & ----- & ----- \\
\hline
\end{tabular}


along the survey line-1 (Figure 2) under VES-2 (Figure 6(a)) and $1.5 \mathrm{ohm} \cdot \mathrm{m}$ along the survey line-8 (Figure 2) under VES-32 (Figure 6(b)). It is significant to find that the apparent resistivity of saturated zone decreases, in general, towards the sea, indicating the influence of seawater.

Along some geoelectric survey lines, the seawater intrusion extends both laterally and horizontally to the west as pinch-out zones. The seawater intruded aquifers are represented by a pinch-out low resistivity layer that extends out laterally under VES 14 and 15 along survey line-4 with true resistivity that reaches $3.9 \mathrm{ohm} \cdot \mathrm{m}$ under the sounding point VES 14 (Figure 7(a)) and along the survey line-6 under VES 22, 23 and 24 (Figure 7(b)), where the resistivity reaches $2.5 \mathrm{ohm} \cdot \mathrm{m}$ corresponding to the sounding point VES 22. Generally, it is observed that the apparent resistivity of saturated zone decreases towards the sea, indicating the influence of seawater. This seawater invasion phenomenon may be controlled by the lateral lithologic variations. These lithologic variations are interpreted as alluvial sediments of ancient and buried wadi channels. These ancient channels and filling sediments could represent potential pathways for saltwater intrusion and form hydraulic connection between the shallow aquifer beds and the seawater.

\section{Conclusion}

Vertical Electric Sounding survey was conducted at 41 locations to assess the types and thickness of different geo-electrical layers to gain an understanding on the aquifer system along the coastal zone of Jizan area. The results indicate that here the shallow groundwater aquifer is hydraulically in contact with the seawater from the Red Sea. As a sequel to such contamination of the shallow groundwater aquifer by saltwater intrusion makes the existing water wells in Jizan coastal zone at risk. The lithologic characteristics of the highly porous and permeable coastal rocks, in addition to the prevailing structural lineaments, further facilitate this hydraulic contamination. In addition to these geological factors, the ongoing heavy pumping of the groundwater due to increasing urban and agricultural water demands and the low precipitation increases the seawater intrusion and consequently the groundwater deterioration. The present results demonstrate that VES surveys are an effective tool for characterization of contaminated zones under the Jizan coast. Evidently, such results bear good potentiality for both planning and remediation strategies.

\section{Acknowledgements}

This project was supported by NSTIP strategic technologies program number (09-SPA873-02) in the Kingdom of Saudi Arabia.

\section{References}

[1] Steeples, D.W. (2001) Engineering and Environmental Geophysics at the Millennium. Geophysics, 66, 31-35. http://dx.doi.org/10.1190/1.1444910

[2] Lapenna, V., Lorenzo, P., Perrone, A., Piscitelli, S., Rizzo, E. and Sdao, F. (2005) 2D Electrical Resistivity Imaging of Some Complex Landslides in the Lucanian Apennine Chain, Southern Italy. Geophysics, 70, B11-B18. http://dx.doi.org/10.1190/1.1926571

[3] Chianese, D. and Lapenna, V. (2007) Magnetic Probability Tomography for Environmental Purposes: Test Measurements and Field Applications. Journal of Geophysics and Engineering, 4, 63-74. http://dx.doi.org/10.1088/1742-2132/4/1/008

[4] Soupios, P.M., Kouli, M., Vallianatos, F., Vafidis, A. and Stavroulakis, G. (2007) Estimation of Aquifer Hydraulic Parameters from Surficial Geophysical Methods: A Case Study of Keritis Basin in Chania (Crete-Greece). Journal of Hydrology, 338, 122-131. http://dx.doi.org/10.1016/j.jhydrol.2007.02.028

[5] Naudet, V., Lazzari, M., Perrone, A., Loperte, A., Piscitelli, S. and Lapenna, V. (2008) Integrated Geophysical and Geomorphological Approach to Investigate the Snowmelt-Triggered Landslide of Bosco Piccolo Village (Basilicata, Southern Italy). Engineering Geology, 98, 156-167. http://dx.doi.org/10.1016/j.enggeo.2008.02.008

[6] Balia, R., Gavaudò, E., Ardau, F. and Ghiglieri, G. (2003) Geophysical Approach to the Environmental Study of a Coastal Plain. Geophysics, 68, 1446-1459. http://dx.doi.org/10.1190/1.1620618

[7] Batayneh, A. (2006) Use of Electrical Resistivity Methods for Detecting Subsurface Fresh and Saline Water and Delineating Their Interfacial Configuration: A Case Study of the Eastern Dead Sea Coastal Aquifers, Jordan. Hydrogeology Journal, 14, 1277-1283. http://dx.doi.org/10.1007/s10040-006-0034-3

[8] Koukadaki, M.A., Karatzas, G.P., Papadopoulou, M.P. and Vafidis, A. (2007) Identification of the Saline Zone in a 
Coastal Aquifer Using Electrical Tomography Data and Simulation. Water Resources Management, 21, 1881-1898. http://dx.doi.org/10.1007/s11269-006-9135-y

[9] Kruse, S.E., Brudzinski, M.R. and Geib, T.L. (1998) Use of Electrical and Electromagnetic Techniques to Map Seawater Intrusion near the Cross-Florida Barge Canal. Environmental \& Engineering Geoscience, 4, 331-340. http://dx.doi.org/10.2113/gseegeosci.IV.3.331

[10] Nowroozi, A.A., Horrocks, S.B. and Henderson, P. (1999) Saltwater Intrusion into the Freshwater Aquifer in the Eastern Shore of Virginia: A Reconnaissance Electrical Resistivity Survey. Journal of Applied Geophysics, 42, 1-22. http://dx.doi.org/10.1016/S0926-9851(99)00004-X

[11] Abdul Nassir, S.S., Loke, M.H., Lee, C.Y. and Nawawi, M.N.M. (2000) Salt-Water Intrusion Mapping by Geoelectrical Imaging Surveys. Geophysical Prospecting, 48, 647-661. http://dx.doi.org/10.1046/j.1365-2478.2000.00209.X

[12] Sherif, M., Mahmoudi, A.E., Garamoon, H., Kacimov, A., Akram, S., Ebraheem, A. and Shetty, A. (2006) Geoelectrical and Hydrogeochemical Studies for Delineating Seawater Intrusion in the Outlet of Wadi Ham, UAE. Environmental Geology, 49, 536-551. http://dx.doi.org/10.1007/s00254-005-0081-4

[13] Cimino, A., Cosentino, C., Oieni, A. and Tranchina, L. (2008) A Geophysical and Geochemical Approach for Seawater Intrusion Assessment in the Acquedolci Coastal Aquifer (Northern Sicily). Environmental Geology, 55, 1473-1482. http://dx.doi.org/10.1007/s00254-007-1097-8

[14] Khalil, M.H. (2006) Geoelectric Resistivity Sounding for Delineating Salt Water Intrusion in the Abu Zenima Area, West Sinai, Egypt. Journal of Geophysics and Engineering, 3, 243-251. http://dx.doi.org/10.1088/1742-2132/3/3/006

[15] Blank, H.R., Johnson, P., Gettings, M.E. and Simmons, G.C. (1985) Explanatory Notes to the Geologic Map of the Jizan Quadrangle, Sheet 16F. Deputy Ministry for Mineral Resources, Ministry of Petroleum and Mineral Resources, Kingdom of Saudi Arabia.

[16] Hussain, M. and Ibrahim, K. (1997) Electric Resistivity, Geochemical and Hydrogeological of Wadi Deposits, Western Saudi Arabia. Journal of King Abdulaziz University: Earth Sciences, 9, 55-72.

[17] Greenwood, W. (1985) Geologic Map of the Abha Quadrangle, Sheet 18F. Deputy Minister for Mineral Resources, Jeddah, Scale 1:250,000.

[18] Prinz, W. (1984) Geologic Map of the Jibal Hai’l Quadrangle, Sheet 17E. Deputy Minister for Mineral Resources, Jeddah, Scale 1:250,000.

[19] Fairer, G.M. (1985) Geologic Map of Wadi Baysh Quadrangle, Sheet 17F. Deputy Minister for Mineral resources, Jeddah, Scale 1:250,000.

[20] Basahel, A., Bahafzalla, A., Mansour, H. and Omara, S. (1983) Primary Structures and Depositional Environ of the Haddat Ash Sham Sedimentary Sequence, Northwest of Jeddah, Saudi Arabia. Arab Gulf Journal of Scientific Research, 1, 143-155.

[21] Hussein, M. and Bazuhair, A. (1992) Groundwater in Haddat Al Sham-Al Bayada Area, Western Saudi Arabia. Arab Gulf Journal of Scientific Research, 1, 23-43.

[22] Al-Bassam, A.M. and Hussein, M.T. (2008) Combined Geo-Electrical and Hydro-Chemical Methods to Detect SaltWater Intrusion. Management of Environmental Quality: An International Journal, 19, 179-193. http://dx.doi.org/10.1108/14777830810856564

[23] Al-Amri, A. (1998) The Application of Geoelectrical Vertical Soundings in Delineating the Hydrostratigraphy of the Southern Red Sea Coastal Area, Saudi Arabia. Journal of King Abdulaziz University: Earth Sciences, 10, 73-90.

[24] Al Hazmi, A. (2005) Salt Water Intrusion in Coastal Aquifer in Jazan, Kingdom of Saudi Arabia. Master’s Thesis, King Saud University, Riyadh.

[25] Bernard, J. (2003) Definition of Main Hydrogeological Parameters Electrical Methods for Groundwater Magnetic Resonance Method for Groundwater. Short Note on the Principles of Geophysical Methods for Groundwater Investigations.

[26] Choudhury, K. and Saha, D.K. (2004) Integrated Geophysical and Chemical Study of Saline Water Intrusion. Ground Water, 42, 671-677. http://dx.doi.org/10.1111/j.1745-6584.2004.tb02721.x

[27] Elawadi, E., Mogren, S., Ibrahim, E., Batayneh, A. and Al-Bassam, A. (2012) Utilizing Potential Field Data to Support Delineation of Groundwater Aquifers in the Southern Red Sea Coast, Saudi Arabia. Journal of Geophysics and Engineering, 9, 327-335. http://dx.doi.org/10.1088/1742-2132/9/3/327 